Article

\title{
Impacts of Leadership on Project-Based Organizational Innovation Performance: The Mediator of Knowledge Sharing and Moderator of Social Capital
}

\author{
Junwei Zheng ${ }^{1}$ (D), Guangdong $\mathrm{Wu}^{2}$ (D) and Hongtao Xie ${ }^{1, *}$ \\ 1 Faculty of Civil Engineering and Mechanics, Kunming University of Science and Technology, \\ Kunming 650500, China; zjw1989@kmust.edu.cn \\ 2 Department of Construction Management, Jiangxi University of Finance and Economics, \\ Nanchang 330013, China; gd198410@163.com \\ * Correspondence: xhtkmust@kmust.edu.cn; Tel.: +86-137-5914-3607
}

Received: 21 September 2017; Accepted: 17 October 2017; Published: 20 October 2017

\begin{abstract}
With the increasing importance of leadership in project-based organizations, innovation is essential for the sustainable development of construction projects. Since few studies have explored the relationship between leadership and innovation in construction projects, this study fills this research gap and makes a significant theoretical contribution to the existing body of literature. Based on a knowledge-rated and resource-based view, this study aims to investigate various effects of different types of leadership on innovation performance in a construction project-based organization. Therefore, a theoretical model was constructed to explore the mediation mechanism and boundary condition of different types of leadership to improve innovation. The theoretical model was validated with empirical data covering project managers and engineers from the project-based organization in China via regression analysis and path analysis. The results show that transformational leadership and transactional leadership have some positively significant effects on knowledge sharing and innovation performance. Meanwhile, knowledge sharing partially mediates the relationship between transformational leadership and/or transactional leadership and innovation performance. Additionally, by considering different levels of social capital, transformational leadership is likely to have a strong positive impact on innovation performance through knowledge sharing. Our findings ensure a better understanding of the role of leadership, knowledge management, and social capital in the innovation process of construction projects. Therefore, project managers should promote a higher stimulation of a leadership behavior, encouraging knowledge management, and establishing the social capital, thus improving the innovation performance in the project-based organizations in construction projects.
\end{abstract}

Keywords: leadership; innovation performance; knowledge sharing; social capital; project-based organization

\section{Introduction}

With the rapid development of the construction technology, the construction industry has become more knowledge-intensive, thus it became imperative to carry on innovation by the sustainability trends [1]. Innovation in construction is beneficial for the sustainability (i.e., competitiveness improvement) of the construction industry and firms, and the sustainability (i.e., quality and technical level) of the construction projects. The innovation level in the construction industry attracts both criticism [2] as well as praise [3]. On the one hand, the initial criticism was that construction 
lags behind the innovativeness of the manufacturing and service sectors [4]. On the other hand, Pries and Janszen [5] stated that construction is inherently innovative. The form of project-based organization was adopted by increasing construction companies to improve project efficiency and performance [6], which was seen as a form of the organization where different parties participated. Faced with a different complexity of the various construction projects and considering sustainability demand, the construction project-based organization would start addressing the challenge of sharing knowledge and coordinating the relationship to carry out innovation [7]. The project-based character of construction activities that are practiced due to a strong price orientation, are by several scholars seen as for a lack of knowledge transfer and innovation [8]. Furthermore, various factors are hampering innovation in construction, such as the conservation of established practices, fear of future collaboration, perceived high financial investment needed in innovation, and limited time-span and resources [9]. As a result, how to drive innovation in a construction project-based organization has become an emerging topic and pressing issue.

Consist with OECD definition [10], innovation is defined as a new or significantly improved product (good or service), process (production or delivery method), marketing method or managerial method [11]. Park et al. [12] defined innovation as the generation, development, and implementation of ideas that are new to an organization and have practical or commercial benefits. Thus, the term innovation is closely related to organization. Meanwhile, it is well documented that innovation is essential to various aspects of the organizational performance [9]. Previous studies investigated many factors that predicted organizational innovation, including organizational strategy [13], organizational learning [14], communication and engagement of stakeholders [15] and positive expectations of innovation from the team [16]. First, leadership is essential for enacting and implementing an innovative organizational strategy and structure, promoting organizational learning, and motivating team visions towards innovation. Therefore, leadership has been regarded as one of the most important factors in determining the degree to which employees strive for innovation. Although previous studies identify leadership as a critical factor in the development of innovation in construction [17,18], detailed or in-depth studies on the effectiveness of different types of leadership on innovation performance in construction projects are still in their infancy. Besides, a large part of the literature focused on innovation at the firm level [19], thus a limited number of studies mentioned innovation from an inter-organizational perspective in construction underlying the cooperation of members engaged in construction projects [20].

Second, knowledge sharing has acted as an important enabler for innovation [1,21]. Innovation is associated with the change of information [22]. Knowledge sharing enables a transfer of experience which avoids a repetition of mistakes in a construction project-based organization [23]. According to the knowledge-based view, the project-based organization in construction acts as the knowledge platform for the members and the basis for integrating multidisciplinary expertise [7,24]. Knowledge exchange provides the information channels to facilitate communication between partners in organization [25]. Although there is an increasing attention of knowledge sharing in the organization, the focus on knowledge sharing of construction project-based organization still remains rather poor [26].

Third, the construction project-based organization, acts as the temporary organization in a construction project, in which the members and resources are aggregated. The way individual linked, the tangible and intangible resources exchanged between members, are referred to as project social capital [27]. Although previous studies found that social capital benefits organizational outcomes, whether and how the social capital of construction projects influences the innovation performance in the project-based organization setting is still a topic to be considered. Besides, access to knowledge is important for the organizational performance, and the project social capital provides an arena for members to use knowledge as resources. Thus, it is essential to explore the inner relationship between knowledge sharing and social capital in the construction project-based organization.

This study considers a project-based organization from an inter-organization perspective to emphasize the importance of coordination, knowledge exchange and mutual relationship among 
different parties in the construction projects. Hence, this study mainly focuses on the inter-organization level of construction projects, aiming to fill this research gap and by investigating the mechanism between different types of leadership and construction project-based organizational innovation performance. To obtain an intensive understanding of the impact of different types of leadership on innovation performance in construction projects, this study reveals the internal mechanism used for fostering knowledge exchange and identifying the association with social capital. The reliability test, validity test, regression analysis and moderated path analysis are incorporated in this study to analyze the relationships among different leadership styles, knowledge sharing, social capital, and project-based organizational innovation performance in construction projects. The main theoretical implications of our findings are the following: (i) Transformational leadership and transactional leadership act as the precursor of knowledge sharing and innovation performance, while knowledge sharing partially transmits the effect of leadership on innovation performance. (ii) Project social capital acts as the moderation mechanism, in which the effect of transformational leadership on innovation performance via knowledge sharing are amplified. To sum up, this study not only addresses both key leadership (i.e., transformational leadership and transactional leadership) in construction project-based organization, but also investigates the mediation role of knowledge sharing and the boundary condition of social capital to capture the mechanism used to improve innovation performance in a construction project-based organization. This study establishes a concept model to introduce the leadership styles into a construction project-based organization, and by employing the contingent model it tests how transformational leadership, transactional leadership and knowledge sharing interact with social capital to influence innovation performance. This study provides a more integrative view of how leaders may stimulate project-based organizational innovation in construction projects by facilitating knowledge sharing and improving relationships with the team members and stakeholders.

The rest of the paper is structured as follows. Section 2 discusses the literature review and various hypothesis formulations. Section 3 deals with sample selection, scales design, reliability test, factor analysis, and methodology. Section 4 deals with measurement models assessment and hypothesis testing. Section 5 discusses the results. Finally, conclusions, implications, limitations and future directions are drawn in the last section.

\section{Literature Review and Research Hypotheses}

Previous studies on organizational leadership highlight that a critical mission of leaders is to facilitate followers to engage in activities that strive for the achievement of group and/or organization goals [28], although not all leaders are equally inclined to motivate the followers to be innovative. In this study, different leadership styles, i.e., transformational leadership and transactional leadership, are proposed as key variables to encourage and motivate followers to engage in innovative actions in construction projects. The central factors of the mechanism transferring or regulating the effects of two leadership types are knowledge sharing and social capital. The hypothesized relationships are depicted in Figure 1, which describes the theoretical framework used in this study. 


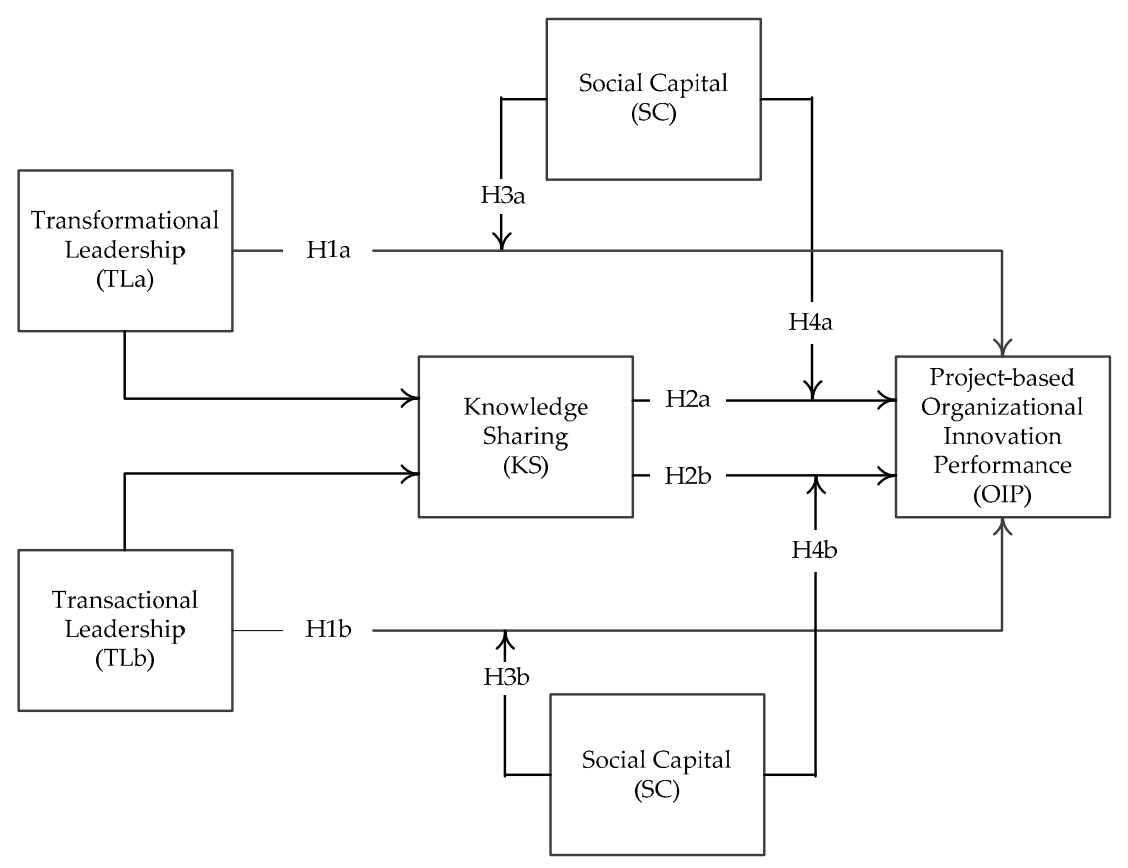

Figure 1. The theoretical model.

\subsection{Main Effects: Leadership Styles and Project-Based Organizational Innovation Performance}

The concepts of transformational and transactional leadership have long been adopted in previous studies [29,30]. Transformational and transactional leadership are also the two main leadership styles on which we have focused in this study. On the one hand, transformational leadership refers to leaders focusing on meeting the higher-order intrinsic needs of their followers, resulting in followers identifying themselves with the needs of their leader [31]. It has four dimensions: charisma (or idealized influence), inspirational stimulation, intellectual stimulation and individualized consideration [30]. On the other hand, transactional leadership refers to leaders focusing on satisfying the extrinsic needs of their subordinates, such a focus results in the subordinates performing the tasks that their leader requires [31]. It involves contingent rewards and management by exception [30].

The effects that different types of leadership might have on innovation vary in the literature. The transformational leader motivates the employees to strive for the collective goals, and stimulating followers' focus and understanding towards the organizational vision [32]. For example, Bass and Riggio [33] suggested that transformational leadership enhances the creative effort in an organization and contributes to the innovative goal. Transformational leadership is a strong supporter of the unconventional things that foster innovation and improve performance [34]. According to Bass and Riggio [33], a leader having a contingent reward behavior would obtain employees' prior agreement on the job to be done in exchange of rewards for delivering the performance within a time frame. Moreover, a leader promoting an active management by exception supervises employees, identifies errors or mistakes, and then takes corrective actions. Additionally, the project' success partially depends on the manager's leadership style [35], thus the leadership has a great influence on the performance of the construction work [36]. Empirical studies exhibited the effects of transformational or transactional leadership on the innovation and performance of organizations $[37,38]$. The empirical evidence in the relevant literature is still ambiguous (e.g., [9,39]), and the conclusion always emphasize the positive influence of transformational leadership when compared with transactional leadership [40]. Furthermore, studies focusing on the relationships among transformational leadership, transactional leadership and innovation performance at the inter-organization level are still rare, referring to the construction project-based organization in which different parties of construction projects are engaged. Thus, it is commonly believed that transformational leadership and transactional leadership will have a 
significant and positive impact on organizational performance, mainly on the innovation performance in the project-based organization.

Hypothesis 1a. Transformational leadership is positively related to innovation performance of the construction project-based organization.

Hypothesis $\mathbf{1 b}$. Transactional leadership is positively related to innovation performance of the construction project-based organization.

\subsection{Mediation Effects: Knowledge Sharing}

Innovation is one of the most knowledge-intensive activities [41]. Knowledge-intensive activities are simultaneously essential for innovation in the organization operation process [42], and enable interaction and promote the connection among actors in the organization [43]. Knowledge management is a pre-requisite for creating, sharing, and storing creative ideas. Effective leadership plays a significant role in promoting a supportive climate for exposing knowledge into organization innovation [34]. Knowledge management refers to all managerial activities which helps individuals in the organization to create new knowledge and share this knowledge with others in order to improve the performance of the organization [27]. Both knowledge sharing and knowledge application have been known to facilitate the creation of new ideas and processes so that it can improve the performance of the organizations.

Furthermore, Birasnav [44] proposed that knowledge management plays a mediation role in the relationship between transformational leadership and organizational performance, when controlling the impact of transactional leadership. Singh [45] investigated the role of leadership in the knowledge management process. Han [46] also exhibited the effect of transformational leadership and knowledge sharing. In addition, Bryant [47] proposed that leaders contribute to improving performance through exploiting knowledge in the organizations. Moreover, the previous studies focus on the associations between leadership and knowledge sharing at the firm level [48], and an important strand of literature concluded that knowledge management or knowledge sharing contribute significantly to innovation efforts and help ameliorate organizational performance at the firm level [49]. However, this type of studies in the construction projects is still rare. Hence, transformation leaders nurture the intrinsic needs to share knowledge while transaction leaders involve in providing rewards to share knowledge. It is also expected that such leaders enhance innovation performance of project-based organization through the process of knowledge sharing in the construction projects. Based on the above discussion, the hypotheses developed are the following.

Hypothesis 2a. Knowledge sharing would mediate the relationship between transformational leadership and project-based organizational innovation performance.

Hypothesis $\mathbf{2 b}$. Knowledge sharing would mediate the relationship between transactional leadership and project-based organizational innovation performance.

\subsection{Moderating Effects: Social Capital}

According to the social capital theory, social capital is both a tangible and intangible resource to organizations to be used appropriately. Social capital is associated with the extent to which people share information, and are concerned with the resources embedded in the relationship network [50]. Further, it is possible to obtain the necessary resources for new technology adoption and technology improvement [51]. Capital acts like a precursor to organizational innovation and performance [52]. Previous studies focusing on the impact of transformational leadership have predominantly studied human capital rather than social capital $[53,54]$. Social capital theory suggests 
that social relationships among organizational members and those with outside actors, confer vital resources such as information or advices among others, all representing important preconditions for information sharing, knowledge creation, and innovation [55]. The leadership style is a combination of characteristics, skills and behavior that the managers uses to interact with employees [56]. Leaders manage and influence a vital part of the resources through social capital, though a few studies addressed the effects of transformational leadership and transactional leadership on social capital [57]. It is essential to study how different leadership styles leverage social capital to foster innovation. Moreover, social capital research has been somewhat neglected in the construction projects. Thus, the research hypotheses used in our research are the following.

Hypothesis 3a. Social capital moderates the positive relationship between transformational leadership and project-based organizational innovation performance, so that this relationship is stronger in the presence of higher social capital.

Hypothesis $3 \mathbf{b}$. Social capital moderates the positive relationship between transactional leadership and project-based organizational innovation performance so that this relationship is stronger in the presence of higher social capital.

Social capital can facilitate access to information and vital sources in order to promote performance [58]. For example, Golmoradi et al. [59] stressed that an organization with powerful social capital could have immediate access to a wide range of information in order to create an innovative performance. Social capital is useful in the process of sharing knowledge through some components such as trust and cooperation, thus it will improve the innovative performance of the organization [60]. Additionally, social capital could also impact organizations' efficiency in different ways, by using knowledge sharing and innovation [61]. Alvani et al. [62] noted that social capital is considered as a value, shared by the people who are involved in social networks due to common cultural norms, effective interactions, mutual trust and personal relationships.

As articulated in the previous section, it is logical to further predict that the heightened innovation performance considers the role of social capital, resulting from the positive path between leadership styles and knowledge sharing, and the positive interactions between knowledge sharing and social capital. Thus, there could be registered some moderated mediation effects [63]. Based on this argument, we expect social capital to moderate the indirect effect of leadership on project-based organizational innovation performance via knowledge sharing.

Hypothesis 4a. The indirect transformational leadership on project-based organizational innovation performance via knowledge sharing is moderated by social capital, so that the indirect effect is more positive when social capital is high than when it is low.

Hypothesis $\mathbf{4 b}$. The indirect transactional leadership on project-based organizational innovation performance via knowledge sharing is moderated by social capital, so that the indirect effect is more positive when social capital is high than when it is low.

\section{Methods}

\subsection{Sample}

The sample for the current study was composed of project managers or technicians joining the construction projects in China. Project managers and technicians can be grouped into the same project team or different project teams. Our data collection investigated the team members from various construction projects. A total of 340 questionnaires are distributed to potential respondents. The questionnaires include the basic information of project and measured items, such as 
types of construction projects, transformational leadership, transactional leadership, social capital, knowledge sharing, and project-based organizational innovation performance. All 288 managers or technicians completed this final survey. We eliminated 20 participants for improperly completing the questionnaires, e.g., the missing data and the regular answers. Continuing, $28.73 \%$ (77) of the final sample worked on the building construction projects, $31.72 \%$ (85) were engaged in the highway construction projects, and $21.64 \%$ (58) joined in the railway construction projects. The population of the project-based organization was usually aged 20-50 (29.48\%). The investment of the construction projects was usually between RMB 100 million yuan and RMB 1 billion yuan (42.91\%). The respondents' profile is shown in Table 1.

Table 1. Descriptive statistics of sample frame.

\begin{tabular}{ccc}
\hline The Basic Information of Construction Projects & Number & Percentage \\
\hline The project type joined in & & \\
\hline Building construction project & 77 & 28.73 \\
Municipal infrastructure & 18 & 6.72 \\
Highway construction project & 85 & 31.72 \\
Railway construction project & 58 & 21.64 \\
Hydraulic construction project & 24 & 8.96 \\
others & 6 & 2.24 \\
\hline The population of project-based organization & & \\
\hline $200+$ & 49 & 18.28 \\
$100-200$ & 52 & 19.40 \\
$50-100$ & 63 & 23.51 \\
$20-50$ & 79 & 29.48 \\
$0-20$ & 25 & 9.33 \\
\hline The investment (RMB, yuan) of the construction project engaged & & \\
\hline 1 billion+ + million-1 billion & 87 & 32.46 \\
$50-100$ million & 115 & 42.91 \\
$10-50$ million & 28 & 10.45 \\
$0-10$ million & 29 & 10.82 \\
Total & 9 & 3.36 \\
\hline
\end{tabular}

\subsection{Measures}

We used five-point Likert scales ranging from 1 = "strongly disagree" to $5=$ "strongly agree" to measure the observed variables. All items in the survey were presented in Chinese because our respondents were Chinese. Since the original scales were mostly developed in English, all of the items underwent a back-translation process [64].

\subsubsection{Transformational Leadership}

The transformational leadership was rated by the members of the construction project-based organizations with a five-item scale developed by Bass et al. [65] and McColl-Kennedy et al. [66], combining with the Chinese context. The Cronbach's alpha was 0.913. A sample item was "The leader could increase my level of enthusiasm". EFA led to a one-factor solution (eigenvalue $=3.722$, each factor loading $>0.800$, explaining $74.444 \%$ of the total variance). The CFA result $\left(\chi^{2} / d f=1.793\right.$, RMSEA $=0.054, \mathrm{CFI}=0.995, \mathrm{TLI}=0.991)$ shows that the transformation leadership measure (5 items) fits well in our data.

\subsubsection{Transactional Leadership}

Transactional leadership was a four-item scale developed by Podsakoff et al. [67]. The Cronbach's alpha was 0.903 . A sample item was "The leader always gives me positive feedback when I perform well". The EFA yielded a single-factor solution with each factor loading $>0.800$, explaining the $77.524 \%$ 
of the total variance. The CFA result $\left(\chi^{2} / d f=3.691, \mathrm{RMSEA}=0.100, \mathrm{CFI}=0.992, \mathrm{TLI}=0.977\right)$ shows that the transactional leadership measure fits well in our data.

\subsubsection{Social Capital}

Social capital was assessed within a project of four-item scale developed by Chen et al. [68] and Tsai et al. [61]. The scale focuses on the relationship regarding the capital dimension. A representative item was "We support each other when facing change". The Cronbach's alpha was 0.865. EFA led to a one-factor solution (eigenvalue $=2.853$, each factor loading $>0.700$, explaining $71.320 \%$ of the total variance). CFA results show that the social capital measure almost fits our data $\left(\chi^{2} / d f=4.536\right.$, RMSEA $=0.115$, CFI $=0.986, \mathrm{TLI}=0.959$ ).

\subsubsection{Knowledge Sharing}

Knowledge sharing was assessed using the four-item measure validated by Collins et al. [69]. This scale is focused on the knowledge sharing behavior dimension. Respondents were asked to indicate at work their agreement with statements such as "In the project, we are willing to exchange and combine ideas to find solutions to problems". The Cronbach's alpha for knowledge sharing was 0.827. The EFA yielded a single-factor solution with each factor loading $>0.600$, explaining $66.099 \%$ of the total variance. CFA results indicate that the knowledge sharing measure almost fits our data $\left(\chi^{2} / d f=4.773, \mathrm{RMSEA}=0.119, \mathrm{CFI}=0.982, \mathrm{TLI}=0.946\right)$.

\subsubsection{Project-Based Organizational Innovation Performance}

A five-item measure was used to assess project-based organizational innovation performance, being developed by Gu et al. [70]. One sample item is "The innovativeness has been improved in the implement process of the project". The Cronbach's alpha for the scale was 0.920. EFA led to a one-factor solution (eigenvalue $=3.795$, each factor loading $>0.800$, explaining $75.902 \%$ of the total variance). The CFA result $\left(\chi^{2} / d f=3.008, \mathrm{RMSEA}=0.087, \mathrm{CFI}=0.989, \mathrm{TLI}=0.979\right)$ indicates that the measure fits well in our data. These results provided construct validity evidence of the project-based organizational innovation performance measure in a Chinese context.

The results of confirmatory factor analysis (CFA) were displayed in Table 2.

Table 2. Results of confirmatory factor analysis.

\begin{tabular}{|c|c|}
\hline Construct & CFA Loading \\
\hline \multicolumn{2}{|l|}{ Transformational leadership $\left(\alpha=0.913 ; \chi^{2} / d f=1.793\right.$, RMSEA $=0.054$, CFI $=0.995$, TLI $\left.=0.991\right)$} \\
\hline TLa1 The leader of project-based organization has a clear understanding of where we are going. & 0.798 \\
\hline TLa3 The leader of project-based organization could increase my level of enthusiasm. & 0.855 \\
\hline TLa4 The leader of project-based organization shows respect for the personal feelings of others. & 0.817 \\
\hline TLa5 The leader of project-based organization encourages us to be team players. & 0.837 \\
\hline TLb1 The leader of project-based organization always gives me positive feedback when I perform well. & 0.807 \\
\hline TLb2 The leader of project-based organization gives me special recognition when my work is good. & 0.919 \\
\hline TLb3 The leader of project-based organization commends me when I do a better than average job. & 0.868 \\
\hline TLb4 The leader of project-based organization frequently acknowledges my good performance. & 0.757 \\
\hline \multicolumn{2}{|l|}{ Social capital $\left(\alpha=0.865 ; \chi^{2} / d f=4.536\right.$, RMSEA $\left.=0.115, \mathrm{CFI}=0.986, \mathrm{TLI}=0.959\right)$} \\
\hline \multicolumn{2}{|l|}{ Knowledge sharing $\left(\alpha=0.827 ; \chi^{2} / d f=4.773\right.$, RMSEA $\left.=0.119, \mathrm{CFI}=0.982, \mathrm{TLI}=0.946\right)$} \\
\hline $\begin{array}{l}\text { KS1 The members of project-based organization are capable of } \\
\text { sharing their expertise to bring new initiatives to fruition. }\end{array}$ & 0.541 \\
\hline KS2 We feel that we have learned from each other by sharing information or ideas. & 0.754 \\
\hline KS3 We are willing to share information or ideas with the other member of project-based organization. & 0.852 \\
\hline KS4 In the project, we are willing to exchange and combine ideas to find solutions to problems. & 0.805 \\
\hline
\end{tabular}


Table 2. Cont.

\begin{tabular}{cc}
\hline Construct & CFA Loading \\
\hline Project-based organizational innovation performance $\left(\alpha=0.920 ; \chi^{2} / d f=3.008\right.$, & 0.833 \\
RMSEA $=0.087$, CFI $=0.989$, TLI $=0.979)$ & 0.789 \\
OIP1 The innovativeness has been improved in the implement process of the project. & 0.883 \\
OIP2 The decision making process has been optimized. & 0.864 \\
OIP3 The quality of construction project has been improved. & 0.812 \\
OIP4 The cost of construction project has been decreased. & OIP5 The profit of construction project has been increased. \\
\hline
\end{tabular}

\subsubsection{Control Variables}

The industrial characteristics of construction projects, the number of project departments, and the investment of construction projects were controlled in this study. The surveyed respondents engaged in five types of projects (building construction project, municipal infrastructure, highway construction project, railway construction project, and hydraulic construction project), numbered $1-5$. We also divided the population of the project department into five levels: 1 (less than 20), 2 (20-50), 3 (50-100), 4 (100-200) and 5 (more than 200). We performed the same action for the investment (RMB, yuan) of the joined projects: 1 (less than $¥ 10$ million), 2 (from $¥ 10$ million to $¥ 50$ million), 3 (from $¥ 50$ million to $¥ 100$ million), 4 (from $¥ 100$ million to $¥ 1$ billion) and 5 (more than $¥ 1$ billion). When testing our hypotheses, we controlled these variables.

\subsection{Analytic Strategies}

First, the reliability test, exploratory factor analysis (EFA) and confirmatory factor analysis (CFA) for each measure are conducted to assess whether their factor structures conform to the anticipated results. We applied the reliability test and exploratory factor analysis (EFA) with the software SPSS 22.0 (Armonk, NY, USA), and discussed these results for each above-mentioned measure.

Second, we conducted a series of CFAs to confirm the distinctiveness of the multi-item variables in the study, including transformational leadership, transactional leadership, social capital, knowledge sharing, and project-based organizational innovation performance. The confirmatory factor analysis (CFA) was assessed using a $\chi^{2}$ test and multiple practical fit indices (TLI, CFI, RMSEA and SRMR) that allow an evaluation of different aspects of the model fit (absolute fit, comparative fit, and parsimony-adjusted fit) [71]. The CFA was performed using the software MPLUS 7.0 (Los Angeles, CA, USA) to test the measurement model including all variables of our study. The CFA results revealed that the hypothesized five-factor model fits our data in the best way, compared to other alternative models. These results provide evidence for the discriminant validity of our measures.

Third, we applied a linear regression analysis using the software Stata 13.0 (College Station, Texas, USA) to test our hypotheses, including the main effect, as well as the mediation and moderation effects. We took knowledge sharing and project-based organizational innovation performance as dependent variables. Then the main effect models were tested with two leadership styles as independent variables. The mediating model took knowledge sharing as the mediator. The moderating model took social capital as the moderator. All regression models' results were assessed in terms of the significance of the coefficients and R-square. Besides, the indirect effects of moderated mediation were tested according to the approach proposed by Edwards and Lambert [63].

The analysis undertaken after data collection, as illustrated in Figure 2, was used to assess the scales that satisfy the requirements of reliability, validity, and test the hypotheses. 


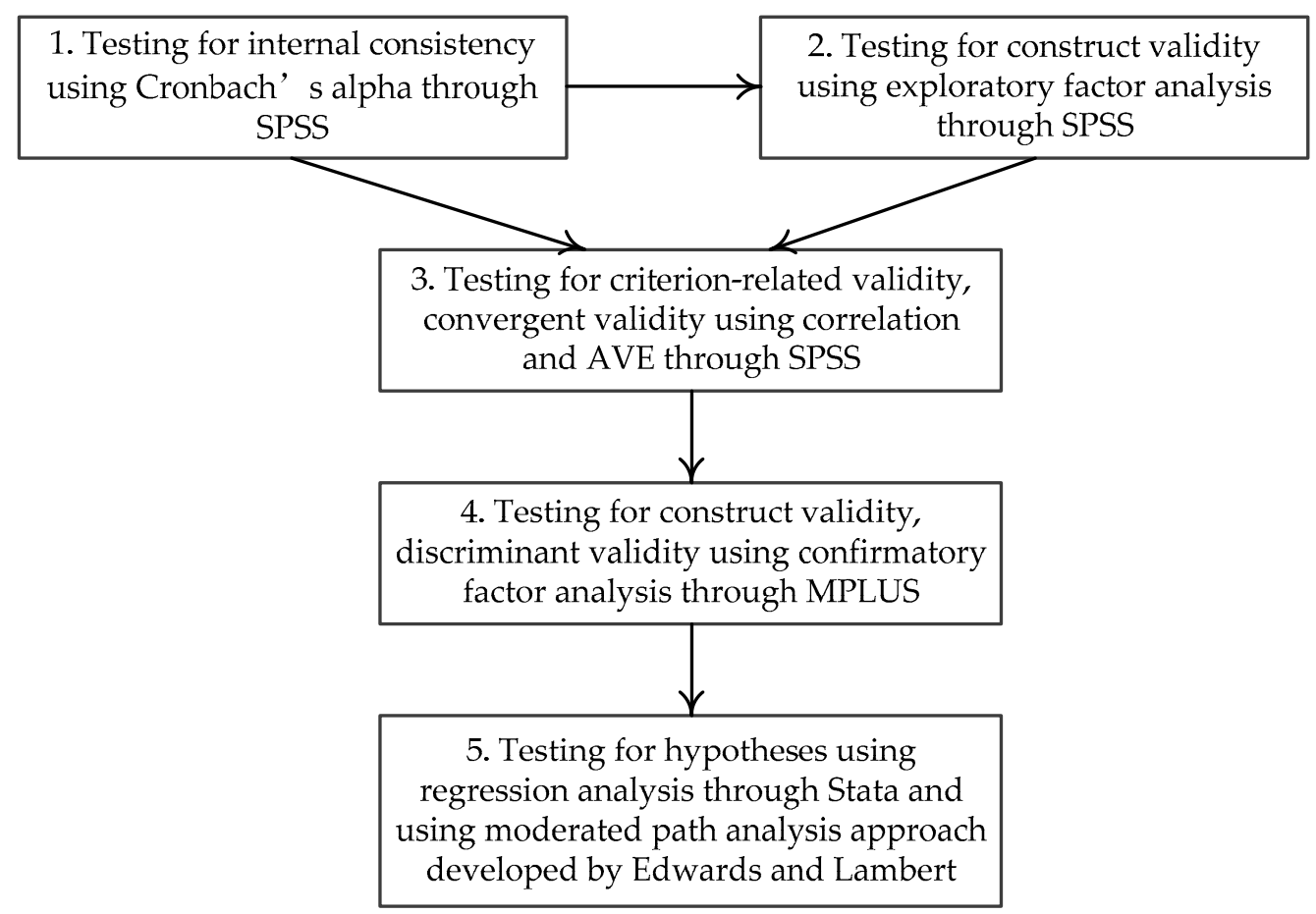

Figure 2. The analysis process.

\section{Results}

Table 3 shows the descriptive statistics and correlation matrix. Compared to the square root of AVE and correlations, the results provided a convergent validity of the study variables.

Table 3. Descriptive statistics and correlations.

\begin{tabular}{lccccccccc}
\hline \multicolumn{1}{c}{ Variables } & Mean & SD & nature & number & invest & TLa & TLb & SC & KS \\
\hline 1. nature & 2.820 & 1.403 & $(-)$ & & & & & \\
2. number & 2.920 & 1.262 & $-0.425^{* *}$ & $(-)$ & & & & \\
3. invest & 2.100 & 1.077 & $-0.351^{* *}$ & $0.504^{* *}$ & $(-)$ & & & \\
4. TLa & 2.637 & 0.799 & 0.068 & -0.025 & 0.026 & $(0.825)$ & & \\
5. TLb & 2.676 & 0.911 & 0.093 & 0.080 & $0.127^{*}$ & $0.437^{* *}$ & $(0.840)$ & & \\
6. SC & 2.592 & 0.833 & -0.014 & $0.131^{*}$ & $0.164^{* *}$ & $0.365^{* *}$ & $0.337^{* *}$ & $(0.791)$ & \\
7. KS & 2.504 & 0.711 & -0.116 & $0.158^{* *}$ & $0.132^{*}$ & $0.413^{* *}$ & $0.424^{* *}$ & $0.409^{* *}$ & $(0.748)$ \\
8. OIP & 2.696 & 0.818 & 0.035 & 0.055 & 0.116 & $0.568^{* *}$ & $0.556^{* *}$ & $0.456^{* *}$ & $0.544^{* *}$ \\
\hline
\end{tabular}

Note: Sample size $=268$; the square root of average variance extraction are in parentheses on the diagonal. SD, standard deviation; Nature, the industry nature of projects; Number, the number of employees in the project department; Invest, the investment of projects; TLa, transformational leadership; TLb, transactional leadership; SC, social capital; KS, knowledge sharing; OIP, project-based organizational innovation performance. ${ }^{*} p<0.05$; $* * p<0.01$. Two-tailed tests.

\subsection{Assessment of the Measurement Model}

As shown in Table 4, the CFA indicated that the expected model with five factors-transformational leadership, transactional leadership, social capital, knowledge sharing, and project-based organizational innovation performance (Model 1) —-demonstrated an excellent fit. All other alternative models (Models 2-4) demonstrated a rather poor fit compared to the hypothesized five-factor model. This is shown by the increased values of $\chi^{2}$, decreased values of TLI and CFI, and increased values of RMSEA and SRMR. 
Table 4. A conducted to examine factor structure of the scales used in the study.

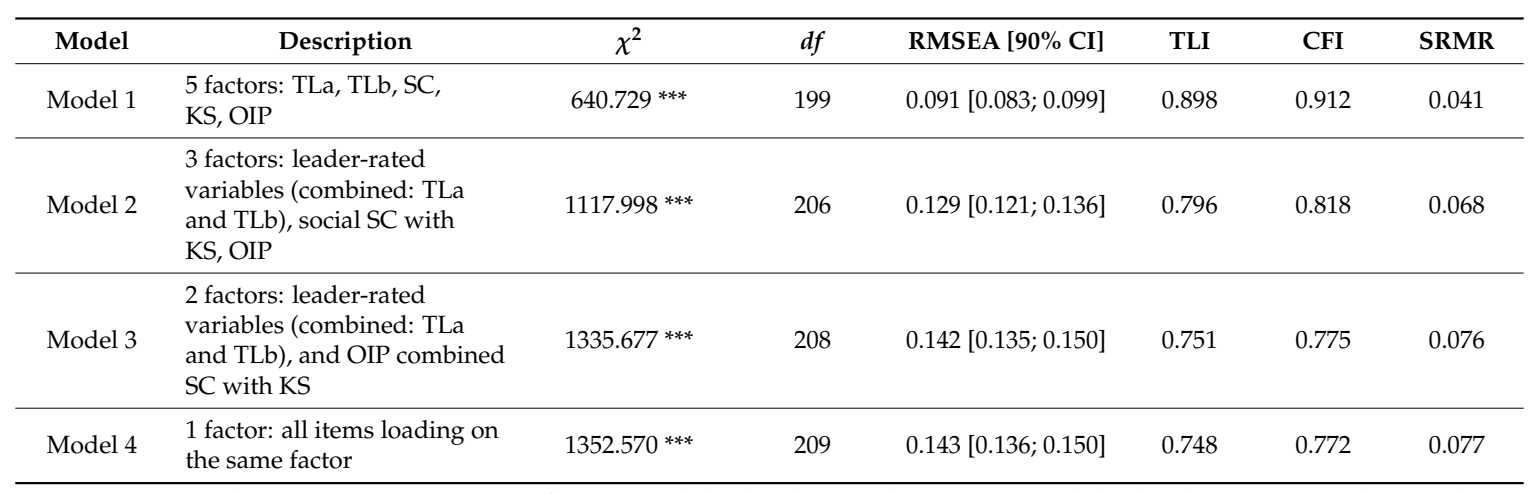

Note: Sample size = 268; TLa, transformational leadership; TLb, transactional leadership; SC, social capital. KS, knowledge sharing; OIP, project-based organizational innovation performance. Model fit was assessed using the recommended cut-offs: 0.90 for TLI [72] and CFI [73]; 0.05 as an indicator of good fit and 0.10 as the upper limit of acceptable fit for RMSEA [74], and 0.08 as an indicator of good fit for SRMR [73]. ${ }^{* *} p<0.001$.

\subsection{Tests of the Research Hypotheses}

Table 5 provides the results of the tests performed on the research hypotheses. We tested the hypotheses in three steps: (1) Mediator $=X_{1}+X_{2}$ (see Model 1 with knowledge sharing as an outcome in Table 5), Mediator means the mediating variable; (2) $Y=X_{1}+X_{2}+$ Mediator (the main effect model and the indirect effect model, respectively; see Model 2 and Model 3 with project-based organizational innovation process as an outcome in Table 5); and (3) $Y=X_{1}+X_{2}+$ Mediator + Moderator $+X_{1} \times$ Moderator $+X_{2} \times$ Moderator + Mediator $\times$ Moderator (the interactive model, see Model 6 in Table 5), Moderator means the moderating variable. The model observed in the first step provided evidence regarding the main effects of two leadership styles on project-based organizational innovation performance (Hypothesis 1). The indirect effect model observed at Step 2 provided evidence regarding the mediating effect of knowledge sharing on the link between leadership and project-based organizational innovation performance (Hypothesis 2). Finally, models observed for all three steps provided evidence of the interactive effect of leadership and knowledge sharing on project-based organizational innovation performance via social capital (Hypothesis 3).

\subsubsection{Main Effect of Transformational Leadership and Transactional Leadership}

As shown by the results registered for Model 2 in Table 5, the main impact of transformational and transactional leadership on project-based organizational innovation performance was positive and statistically significant $\left(\beta_{\mathrm{TLa}}=0.379, p<0.001 ; \beta_{\mathrm{TLb}}=0.621, p<0.001\right)$. This yields support for Hypotheses 1a and $1 \mathrm{~b}$.

4.2.2. Indirect Effects of Transformational Leadership and Transactional Leadership on Project-Based Organizational Innovation Performance via Knowledge Sharing

To test Hypothesis 2 by predicting the mediation effect of knowledge sharing between two leadership styles and project-based organizational innovation performance, we have estimated this indirect effect as a product of three paths [75]: the direct impact of the independent variable, the direct path from the independent variable to the mediator, and path regarding the impact of the mediator. The estimation of knowledge sharing as the mediator was positive and statistically significant $\left(\beta_{\mathrm{KS}}=0.103, p<0.01\right)$, as shown by the results of Model 3 in Table 5 . 
Table 5. Regression analysis results: Main, mediation and moderation effects.

\begin{tabular}{|c|c|c|c|c|c|c|c|c|c|c|}
\hline \multirow{2}{*}{ Variables } & \multirow{2}{*}{$\begin{array}{c}\text { Knowledge Sharing (Mediator) } \\
\text { Model } 1\end{array}$} & \multicolumn{9}{|c|}{ Project-Based Organizational Innovation Performance (Dependent Variable) } \\
\hline & & Model 2 & Model 3 & Model 4 & Model 5 & Model 6 & Model 7 & Model 8 & Model 9 & Model 10 \\
\hline Intercept & $1.234^{* * *}$ & $0.286^{*}$ & 0.140 & 0.263 & $0.363 *$ & 0.234 & -0.271 & 0.280 & $0.817^{* *}$ & 0.345 \\
\hline \multicolumn{11}{|c|}{ Control variables } \\
\hline Nature & $-0.157^{* *}$ & -0.048 & -0.032 & 0.063 & -0.032 & -0.034 & 0.020 & -0.049 & 0.018 & -0.031 \\
\hline Number & -0.070 & 0.015 & 0.022 & -0.005 & 0.054 & 0.021 & 0.008 & 0.045 & 0.002 & 0.054 \\
\hline Invest & 0.028 & -0.018 & -0.021 & $-0.076+$ & -0.013 & -0.020 & -0.036 & -0.005 & -0.032 & -0.013 \\
\hline \multicolumn{11}{|c|}{ Independent variables } \\
\hline TLa & $0.207^{* * *}$ & $0.379 * * *$ & $0.357^{* * *}$ & $0.588 * * *$ & & $0.627^{* * *}$ & $0.687^{* * *}$ & & $0.492 * * *$ & \\
\hline $\mathrm{TLb}$ & $0.506^{* * *}$ & $0.621^{* * *}$ & $0.569^{* * *}$ & & $0.750 * * *$ & $0.442 * * *$ & & $0.875^{* * *}$ & & $0.735^{* * *}$ \\
\hline \multicolumn{11}{|l|}{ Mediator } \\
\hline KS & & & $0.103^{* *}$ & $0.339 * * *$ & $0.179 * * *$ & -0.137 & & & $-0.161+$ & $0.176+$ \\
\hline \multicolumn{11}{|l|}{ Moderator } \\
\hline $\mathrm{SC}$ & & & & & & 0.035 & $0.681^{* * *}$ & $0.252 *$ & 0.116 & 0.028 \\
\hline \multicolumn{11}{|l|}{ Interactions } \\
\hline $\mathrm{TLa} \times \mathrm{SC}$ & & & & & & $-0.472 * *$ & $-0.361 * *$ & & & \\
\hline $\mathrm{TLb} \times \mathrm{SC}$ & & & & & & 0.101 & & -0.238 & & \\
\hline $\mathrm{LS} \times \mathrm{SC}$ & & & & & & $0.451 *$ & & & $0.518^{* *}$ & -0.008 \\
\hline$R^{2}$ & 0.448 & 0.822 & 0.828 & 0.681 & 0.755 & 0.836 & 0.750 & 0.743 & 0.759 & 0.755 \\
\hline
\end{tabular}

Note: Sample size $=268$; Standardized beta coefficients and unstandardized intercept value are reported. Nature, the industry nature of projects; Number, the number of employees in the project department; Invest, the investment of projects; TLa, transformational leadership; TLb, transactional leadership; KS, knowledge sharing; $\mathrm{SC}$, social capital. ${ }^{* * *} p<0.001,{ }^{* *} p<0.01$, ${ }^{*} p<0.05,+p<0.1$. 
A partial mediation effect was also registered. More specifically, the impact of the transformational and transactional leadership as independent variables on knowledge sharing as the mediator was positively significant $\left(\beta_{\mathrm{TLa}}=0.207, p<0.001 ; \beta_{\mathrm{TLb}}=0.506, p<0.001\right)$, reflected by the results of Model 1. In Model 2, there was observed a significant relationship between the independent variables and dependent variable $\left(\beta_{\mathrm{TLa}}=0.379, p<0.001 ; \beta_{\mathrm{TLb}}=0.621, p<0.001\right)$. After entering the mediator knowledge sharing into the regression equation, in which innovation performance was regressed on two leadership styles, the beta values of transformational leadership and transactional leadership significantly decreased ( $\beta_{\mathrm{TLa}}=0.357, p<0.001 ; \beta_{\mathrm{TLb}}=0.569, p<0.001$ ), as seen in Model 3 . The results show that knowledge sharing plays a partial mediator role in the impact of transformational leadership and transactional leadership on project-based organizational innovation performance. This set of analyses supports Hypotheses $2 \mathrm{a}$ and $2 \mathrm{~b}$.

Meanwhile, as shown by the results obtained for Models 4 and 5 in Table 5, there were registered significant relationships between transformational leadership or transactional leadership and project-based organizational innovation performance via knowledge sharing $\left(\beta_{\mathrm{TLa}}=0.588, p<0.001\right.$ and $\beta_{\mathrm{KS}}=0.339, p<0.001 ; \beta_{\mathrm{TLb}}=0.750, p<0.001$ and $\left.\beta_{\mathrm{KS}}=0.179, p<0.001\right)$. This provides additional support for the mediating Hypotheses $2 \mathrm{a}$ and $2 \mathrm{~b}$.

\subsubsection{Moderating the Direct Effects of Social Capital}

On the one hand, Hypothesis 3a stated that social capital amplifies the relationship between transformational leadership and project-based organizational innovation performance. The results obtained for Model 6 in Table 5 show that the interaction between transformational leadership and social capital was significant, though negatively related to the project-based organizational innovation performance $\left(\beta_{\mathrm{TLa} \times \mathrm{SC}}=-0.472, p<0.01\right)$. In addition, as shown in Model 7 , after controlling the effects of transactional leadership, the interaction of transformational leadership and social capital was also statistically significant but negative $\left(\beta_{\mathrm{TLa} \times S C}=-0.361, p<0.01\right)$. Therefore, Hypothesis 3a was not supported.

On the other hand, Hypothesis $3 \mathrm{~b}$ proposed that social capital augments the relationship between transactional leadership and project-based organizational innovation performance. The results of Model 6 in Table 5 show that the interaction of social capital with transactional leadership was not statistically significant $\left(\beta_{\mathrm{TLb} \times \mathrm{SC}}=0.101, p>0.05\right)$. In addition, as shown in Model 8 , after controlling the effects of transformational leadership, the interaction between transactional leadership and social capital was not statistically significant $\left(\beta_{\mathrm{TLb} \times \mathrm{SC}}=-0.238, p>0.05\right)$. This set of analyses does not yield support for Hypothesis $3 b$.

Further, to demonstrate the interaction, we computed a series of estimates of social capital at low (mean - 1 SD) and high (mean + 1SD) values of the moderator [76,77], and we conducted the interaction plots. Figure 3 provides two interaction plots with simple slopes for social capital at one standard deviation below the mean and social capital at one standard deviation above the mean. (i) The results of this additional analysis suggest that transformational leadership and social capital interact to negatively impact the project-based organizational innovation performance, which contradicts Hypothesis 3a. (ii) The results indicate that transactional leadership and social capital interact to not affect the project-based organizational innovation performance, which does not support Hypothesis $3 \mathrm{~b}$.

Besides, we estimated the indirect effect through the moderated path analysis approach using a Bootstrap technique [63], as can be seen in Table 6. The results reported in Table 6, reveal that the estimation of the direct impact of transformational leadership on project-based organizational innovation performance at low social capital was positive and statistically significant $(\beta=0.237,95 \% \mathrm{CI}$ [0.091; 0.355], not containing zero). However, the estimation at high social capital was positive but non-significant ( $\beta=0.014,95 \%$ CI [ $-0.239 ; 0.283]$, containing zero). This set of analyses is consistent with the plot in Figure 3a, suggesting that the moderating effect of social capital becomes noticeable at lower levels. However, the direct moderation effects were negative and significant because the paths from transformational leadership to project-based organizational innovation performance differed 
significantly across different levels of social capital $(\Delta \beta=-0.223,95 \%$ CI $[-0.333 ;-0.050]$, not containing zero). This result coincides with the regression analysis of Model 7 in Table 5, contradicting Hypothesis $3 a$.

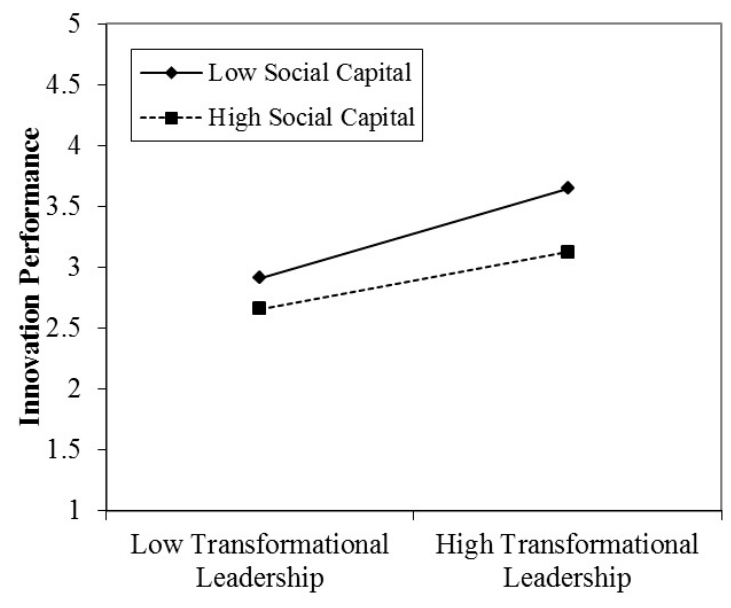

(a)

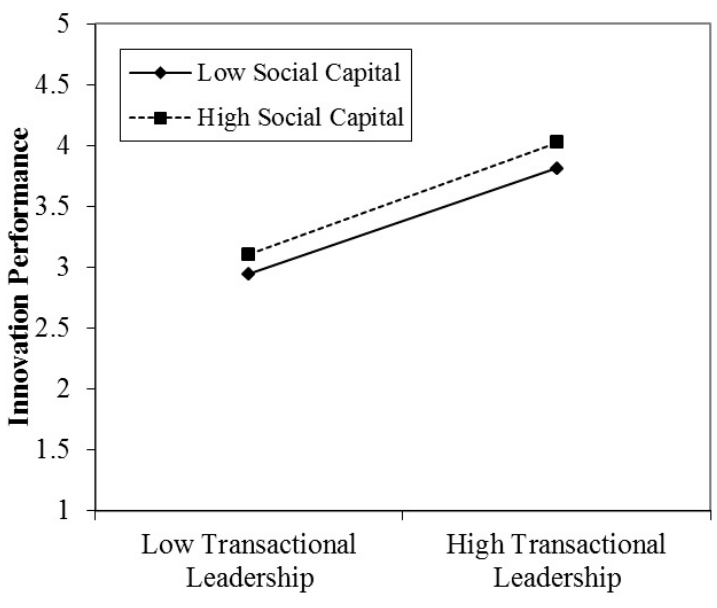

(b)

Figure 3. The interactive effects of: (a) social capital and transformational leadership on project-based organizational innovation performance; and (b) social capital and transactional leadership on project-based organizational innovation performance.

Table 6. Results of the moderated path analysis.

\begin{tabular}{|c|c|c|c|}
\hline \multirow[t]{2}{*}{ Moderator Variable: Social Capital } & \multicolumn{3}{|c|}{$\begin{array}{c}\text { Transformational Leadership }\left(\mathrm{X}_{1}\right) \rightarrow \text { Knowledge Sharing }(\mathrm{M}) \rightarrow \text { Project-Based } \\
\text { Organizational Innovation Performance }(\mathrm{Y})\end{array}$} \\
\hline & Second Stage $[95 \% \mathrm{CI}]$ & Direct Effect $[95 \% \mathrm{CI}]$ & Indirect Effect $[95 \% \mathrm{CI}]$ \\
\hline Low Social Capital (-1 SD) & $0.352[0.208 ; 0.502]$ & $0.237[0.091 ; 0.355]$ & $0.179[0.116 ; 0.264]$ \\
\hline High Social Cap & $0.603[0.300 ; 0.854]$ & $0.014[-0.239 ; 0.283]$ & $0.308[0.201 ; 0.441]$ \\
\hline Differences & $0.252[0.102 ; 0.383]$ & $-0.223[-0.333 ;-0.050]$ & $0.128[0.075 ; 0.183]$ \\
\hline \multirow[t]{2}{*}{ Moderator Variable: Social Capital } & \multicolumn{3}{|c|}{$\begin{array}{c}\text { Transactional Leadership }\left(\mathrm{X}_{2}\right) \rightarrow \text { Knowledge Sharing }(\mathrm{M}) \rightarrow \text { Project-Based } \\
\text { Organizational Innovation Performance }(\mathrm{Y})\end{array}$} \\
\hline & Second Stage $[95 \% \mathrm{CI}]$ & Direct Effect $[95 \% \mathrm{CI}]$ & Indirect Effect $[95 \% \mathrm{CI}]$ \\
\hline Low Social Capital (-1 SD) & $0.282[0.112 ; 0.447]$ & $0.526[0.341 ; 0.695]$ & $0.175[0.077 ; 0.294]$ \\
\hline High Social Capital (+1 SD) & $0.379[0.043 ; 0.688]$ & $0.374[0.012 ; 0.667]$ & $0.235[0.391 ; 0.806]$ \\
\hline Differences & $0.097[-0.100 ; 0.250]$ & $-0.152[-0.317 ; 0.033]$ & $0.060[-0.056 ; 0.163]$ \\
\hline
\end{tabular}

Note: Low moderator variable refers to one standard deviation below the mean of the moderator, while high moderator variable refers to one standard deviation above the mean of the moderator; $95 \%$ CI means $95 \%$ confidence interval; it does not contain zero, it means it is significant and vice versa; bootstrap equals 1000; and these were performed using bias corrected percentile method (BC).

In terms of Hypothesis $3 b$, as shown in Table 6, the direct effect of transactional leadership on project-based organizational innovation performance via social capital was significant $(\beta=0.526$, $95 \%$ CI $[0.341 ; 0.695]$, not containing zero) when social capital was low and statistically significant ( $\beta=0.374,95 \%$ CI $[0.012 ; 0.667]$, not containing zero) when social capital was high. However, the difference in the direct effect of the social capital was not significant $(\Delta \beta=-0.152,95 \% \mathrm{CI}$ [ $-0.317 ; 0.033]$, containing zero), providing additional support to the results registered for Model 8 in Table 5. Thus, Hypothesis $3 b$ was not supported. We plotted the moderated direct effects in Figure $3 b$.

\subsubsection{Moderated Indirect Effects by Social Capital}

Hypothesis 4 predicted that social capital moderated the indirect effect of transformational leadership/transactional leadership on project-based organizational innovation performance via 
knowledge sharing. As expected, the results of Model 6 in Table 5 indicated that social capital had a positive moderating impact $\left(\beta_{\mathrm{KS} \times \mathrm{SC}}=0.451, p<0.05\right)$.

More specifically, the moderated path analysis results are registered in Table 6 . The second-stage moderation effect, which reveals that the path from transformational leadership to project-based organizational innovation performance differs significantly $(\Delta \beta=0.252,95 \%$ CI $[0.102 ; 0.383]$, not containing zero). However, we do not register a statistically significant result in terms of the path from transactional leadership to project-based organizational innovation performance across different types of social capital ( $\Delta \beta=0.097,95 \% \mathrm{CI}[-0.100 ; 0.250]$, containing zero).

Meanwhile, the indirect effect of transformational leadership on project-based organizational innovation performance via knowledge sharing was statistically significant $(\beta=0.179,95 \% \mathrm{CI}$ [0.116; 0.264], not containing zero) when social capital was low and significant ( $\beta=0.308,95 \%$ CI [0.201; 0.441], not containing zero) when social capital was high. Overall, the difference in the indirect effect of social capital was statistically significant $(\Delta \beta=0.128,95 \%$ CI $[0.075 ; 0.183]$, not containing zero). Thus, Hypothesis 4 a was supported. The results in Table 6 also indicate that the indirect effect of transactional leadership on project-based organizational innovation performance via knowledge sharing was significant ( $\beta=0.235,95 \%$ CI $[0.391 ; 0.806]$, not containing zero) under high social capital, whereas it was statistically significant ( $\beta=0.175,95 \%$ CI $[0.077 ; 0.294]$, not containing zero) under low social capital. Overall, the difference in the indirect effects by social capital was not statistically significant $(\Delta \beta=0.060,95 \%$ CI $[-0.056 ; 0.163]$, containing zero). Hence, Hypothesis $4 \mathrm{~b}$ was not supported.

Overall, our results provided evidence for the second-stage moderation and moderated the indirect effects by social capital from transformational leadership to project-based organizational innovation performance via knowledge sharing.

To summarize, the results of the hypotheses testing are shown in Table 7.

Table 7. Results of the hypothesized model.

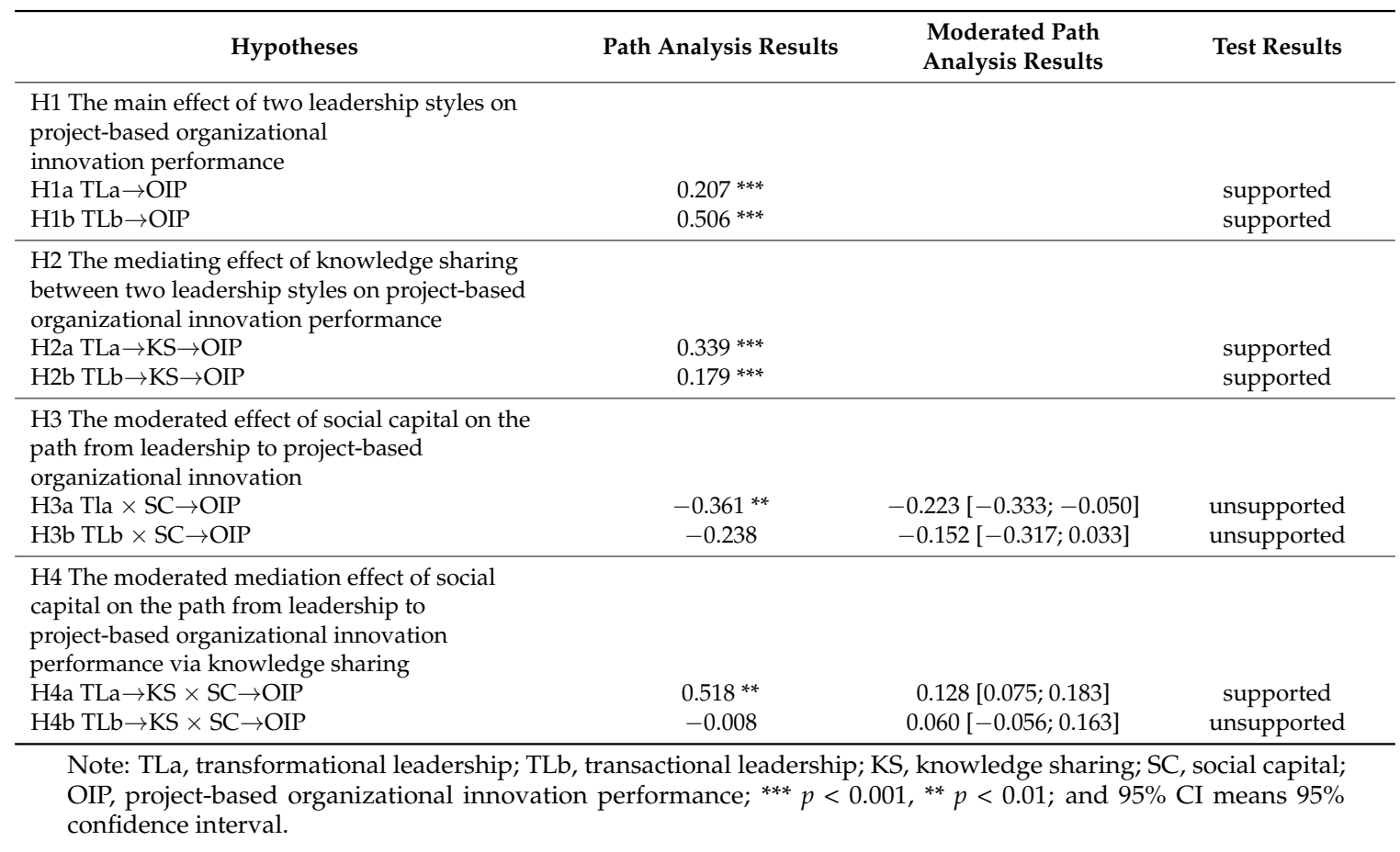

\section{Discussion}

The main objective of this study was to explore how different leadership styles exchange knowledge, coordinate resources and improve innovation in a temporary project-based organization. 
Based on the social capital and knowledge exchange perspective, we proposed knowledge sharing as the mediating mechanism and social capital as the boundary condition for the impact that transformational leadership and transactional leadership on project-based organizational innovation performance.

\subsection{The Differentiation of the Two Leadership Styles}

For construction projects, a leadership style that encourages participation and ideas from followers is expected to determine a higher efficiency in facilitating the project's success [78]. Because knowledge sharing is an enabler of innovation, the leadership style that promotes an open communication of innovative ideas and approaches is essential for organizational innovation [20]. Transformational leaders that nurture the intrinsic development of employees by considering their participation and ideas are essential for an organization [9]. With transformational leadership, innovation is inspired and stimulated among followers.

Compared to transformational leadership, transactional leadership also motivates followers with extrinsic rewards. The construction industry is composed of project-based organizations in which project members who come from different units cooperate as a team in their actions. Moreover, the construction projects are completed within a limited timeframe and resources, thus leaders may find it difficult to apply transformational leadership to nurture the intrinsic long-term needs of employees. Instead, for leaders to execute a less participating leadership behavior may be more effective. This study also found that the transactional leadership style adopting contingent rewards are positively associated with the innovation performance in the construction field, this result being also coherent with previous findings [79]. Meanwhile, the impact of transactional leadership is more than that of transformational leadership style, indicating that, under the context of the limited resources and time, the reward measures could motivate the followers to strive for the short-term goals. Considering innovation as a multistage process, transformational leaders may intervene at a later date in the project's management.

\subsection{The Mediating Role of Knowledge Sharing}

Implementing the knowledge sharing activity is essential for project organizations to facilitate innovation. In this direction, transformational or transactional project managers could develop and combine the knowledge, skills, and capabilities of project members by transferring the knowledge to others and applying that knowledge for completing projects and creating new ideas for organizational or technology innovation. Scholars have provided support for this theory that leadership is positively related to the knowledge management process $[44,80]$. Besides, results advocated that leaders improve the innovation performance via knowledge sharing because the $\mathrm{R}$ square of Model 3 is higher than that of Model 1 in Table 5. Thus, the way in which knowledge sharing occurs help project managers to improve the organizational performance. The internal interaction of knowledge and the external acquisition of knowledge also benefits for stimulating innovation to achieve the sustainability of construction projects and construction innovation [81]. Transformational and transactional leadership in the project organization are the sources of improvement in innovation performance either directly or indirectly through knowledge sharing. These findings suggest that leadership is an important predecessor of knowledge sharing. Thus, transformational or transactional project managers can encourage knowledge sharing in the management process.

\subsection{The Moderating Effect of Social Capital}

First, this study extends the leadership examinations regarding capital. Although transformational leadership is known to positively impact innovation by transmitting through social capital [57], few researchers have tested different leadership styles and their impact within the different levels of social capital. In the project-based organization composed of many stakeholders, our findings support social capital as a significant predecessor in the improvement of innovation performance in the construction 
projects. Nevertheless, the effects of leadership combined with social capital are not as expected. Social capital did not help project managers or leaders to improve innovation performance. More specifically, the transformational leaders' expert a negative impact on innovation performance across different levels of social capital, while the transactional leaders did not vary significantly across different levels of social capital. Besides, our findings also indicate a positive relationship between projects' social capital and innovation performance. Thus, the empirical results show the negative effect or non-significant effect of leadership on innovation performance, demonstrating that there may be other components capable of explaining this mechanism.

Second, the current study extends the leadership and innovation literature by demonstrating a boundary condition regarding the impact of leadership on innovation performance, namely social capital. Our findings indicate that when there is a high social capital relationship in the project organization, leaders are more likely to improve innovation performance through knowledge sharing. This finding suggests that the role of social capital in construction projects is far more complicated than previously considered [27]. Thus, social capital may also serve as a contextual factor facilitating knowledge sharing. In the temporary project-based organization, people work together on complex innovative tasks for a well-defined limited period. It is likely that projects will become highly embedded in a set of project-specific relationships. This determines transformational leaders to promote information generation and exchange within the project-based organizations, where employees are likely to engage in social activities [82]. In addition, there is no significant impact of social capital on the path from transactional leadership to innovation performance via knowledge sharing. Project leaders may provide rewards to employees to share knowledge and enhance performance by implementing some part of the social capital. However, such a condition may be minimal in comparison to the contribution of transformational leaders on innovation performance via knowledge sharing in the project-based context. Thus, by considering the condition of social capital, the project managers promoting a transformational leader behavior have a high potential to contribute to knowledge sharing and innovation performance compared to the effects determined by transactional leaders.

\section{Conclusions and Implications}

\subsection{Conclusions}

Extending towards research leadership and innovation, the present study highlights the role of knowledge sharing and social capital in facilitating innovation performance. Moreover, the construction industry has long since been recognized as an industry with low innovation. To improve sustainability and promote innovation in the construction projects, leadership, knowledge management process and social capital should be enhanced. First, the results of this study reveal that transformation leadership and transaction leadership are positively associated with innovation performance. The results show the need for academics and practitioners in the construction industry to play a greater importance on leadership. Second, to further enhance innovation in the project-based organizations, knowledge sharing should be promoted during the different levels of social capital, as knowledge sharing was found to have a significant impact on innovation. Additionally, the study empirically shows that knowledge sharing partially mediates the relationship between transformational leadership or transactional leadership and innovation performance. Third, the present study highlights that it is transformational project managers, who make a significant contribution to innovation performance through increasing social capital level in the project-based organizations beyond the contributions of transactional leadership on exchanging and sharing knowledge process.

\subsection{Practical Implications}

The results of this study generate several valuable insights with interesting theoretical implications. Compared to the literature, this study developed a conceptual model by integrating a series of concepts, 
namely transformational leadership, transactional leadership, knowledge sharing, social capital and project-based organizational innovation performance. Although a number of investigations indicate the positive effects of different leadership styles on organizational performance, our study built the conceptual model specifying the mediating role of knowledge sharing and the moderating role of social capital. In addition, this study empirically tested the conceptual model and proved five hypotheses. More precisely, transformational leadership and transactional leadership have a direct impact on project-based organizational innovation performance, in the same time observing the indirect impacts on performance through implementing knowledge sharing. Thus, this study provides strong evidence in showing the interrelationships between two leadership styles and knowledge sharing and between two leadership styles and project-based organizational innovation performance. In addition, this study tested the moderated mediation effect of social capital, examining the effects of transformational leadership on innovation performance via knowledge sharing across different levels of social capital. As such, this study emphasized the importance of developing two leadership styles to improve project-based organizational innovation performance through implementing knowledge sharing and building social capital relationships.

Our findings also have important managerial implications. It may be helpful for project leaders or individuals who manage teams in project-based organization setting, providing important insights on the management of inter- or intra-organizational knowledge exchange and network establishment. Our results suggest that through an appropriate leadership style, project-based organization can increase their coordination and knowledge sharing with the management of social capital, thus producing and improving the high levels of innovation performance. The uncovered moderating effect of social capital on the indirect relationship between transformational leadership and project-based organizational innovation performance, leads us to the conclusion that construction project-based organizations could strengthen the relationships among project managers and other members of the organization by launching different interventions. The intervention could be implemented in such a way that it amplifies the number of connections, providing mutual support between managers and other organization members.

\subsection{Limitations and Future Research}

This study has several limitations. First, in this field of study, the surveys used to measure transformational leadership, transactional leadership, knowledge sharing, social capital, and innovation performance were collected concomitantly, although the data were collected from employees engaged in different construction projects, and the same potential source bias was controlled so it did not represent a severe problem. However, in this case, it was extremely difficult to prove causality between different concepts. Therefore, future research should focus on collecting longitudinal data to test the relationships among leadership styles, knowledge management, social capital and innovation performance.

Secondly, the study was performed in China, a market dominated by emerging projects where leadership is essential for accessing external and internal resources. However, the concepts of transformational leadership and transactional leadership come from Western countries, which may not be appropriate in the Chinese construction projects context. Thus, there could be a differential impact between the two leadership styles, while the transformational leadership exerts a weak positive impact compared with transactional leadership in construction project-based setting. Future research could extend the sample to other industries in China or replicate the study to other countries in order to validate the results.

Acknowledgments: This study is supported by the National Natural Science Foundation of China (71701083, 71561009 and 71761021), China Postdoctoral Science Foundation (2016M590605 and 2017T100477), Postdoctoral Science Foundation of Jiangxi Province (2016KY27), Social Science Planning Foundation of Jiangxi Province (16GL32), Natural Science Foundation of Jiangxi Province (S2017QNJJB0493), and Talent Training Foundation of Yunnan Province (KKSY201606041). 
Author Contributions: Junwei Zheng designed this study and completed the paper in English; Guangdong Wu participated in drafting the paper and revised it critically for important intellectual content; and Hongtao Xie gave many good research advices and revised the manuscript.

Conflicts of Interest: The authors declare no conflicts of interest.

\section{References}

1. Wen, Q.; Qiang, M. Coordination and knowledge sharing in construction project-based organization: A longitudinal structural equation model analysis. Autom. Constr. 2016, 72, 309-320. [CrossRef]

2. Blayse, A.M.; Manley, K. Key influences on construction innovation. Constr. Innov. 2004, 4, $143-154$. [CrossRef]

3. Seaden, G.; Manseau, A. Public policy and construction innovation. Build. Res. Inf. 2001, 29, 182-196. [CrossRef]

4. Reichstein, T.; Salter, A.J.; Gann, D.M. Last among equals: A comparison of innovation in construction, services and manufacturing in the UK. Constr. Manag. Econ. 2005, 23, 631-644. [CrossRef]

5. Pries, F.; Janszen, F. Innovation in the construction industry: The dominant role of the environment. Constr. Manag. Econ. 1995, 13, 43-51. [CrossRef]

6. Buvik, M.P.; Rolfsen, M. Prior ties and trust development in project teams-A case study from the construction industry. Int. J. Proj. Manag. 2015, 33, 1484-1494. [CrossRef]

7. Zhang, P.; Ng, F.F. Explaining knowledge-sharing intention in construction teams in Hong Kong. J. Constr. Eng. Manag. 2013, 139, 280-293. [CrossRef]

8. Havenvid, M.I. Competition versus interaction as a way to promote innovation in the construction industry. IMP J. 2015, 9, 46-63. [CrossRef]

9. Chan, I.Y.S.; Liu, A.M.M.; Fellows, R. Role of leadership in fostering an innovation climate in constrction firms. J. Manag. Eng. 2014, 30, 06014003. [CrossRef]

10. The Organization for Economic Co-operation and Development (OECD). Oslo manual: Guidelines for Collecting and Interpreting Technological Innovation Data; OECD: Paris, France, 2005.

11. Manley, K.; McFallan, S.; Kajewski, S. Relationship between construction firm strategies and innovation outcomes. J. Constr. Eng. Manag. 2009, 135, 764-771. [CrossRef]

12. Park, M.; Nepal, M.P.; Dulaimi, M.F. Dynamic modeling for construction innovation. J. Manag. Eng. 2004, 20, 170-177. [CrossRef]

13. Naranjo-Gil, D. The influence of environmental and organizational factors on innovation adoptions: Consequences for performance in public sector organizations. Technovation 2009, 29, 810-818. [CrossRef]

14. Bates, R.; Khasawneh, S. Organizational learning culture, learning transfer climate and perceived innovation in Jordanian organizations. Int. J. Train. Dev. 2005, 9, 96-109. [CrossRef]

15. Widén, K.; Olander, S.; Atkin, B. Links between Successful Innovation Diffusion and Stakeholder Engagement. J. Manag. Eng. 2014, 30, 04014018. [CrossRef]

16. Carlfjord, S.; Lindberg, M.; Bendtsen, P.; Nilsen, P.; Andersion, A. Key factors influencing adoption of an innovation in primary health care: A qualitative study based on implementation theory. BMC Fam. Pract. 2010, 11, 60. [CrossRef] [PubMed]

17. Amabile, T.M.; Schatzel, E.A.; Moneta, G.B.; Karmer, S.J. Leader behaviors and the work environment for creativity: Perceived leader support. Leadersh. Q. 2004, 15, 5-32. [CrossRef]

18. Peterson, H.C. Tranformational suply chanis and the 'wicked problem' of sustainability: Aligning knowledge, innovation, entrepreneurship, and leadership. J. Chain Netw. Sci. 2009, 9, 71-82. [CrossRef]

19. Ozorhon, B. Analysis of Construction Innovation Process at Project Level. J. Manag. Eng. 2013, 29, 455-463. [CrossRef]

20. Ozorhon, B.; Abbott, C.; Aouad, G. Integration and leadership as enablers of innovation in construction: Case study. J. Manag. Eng. 2014, 30, 256-263. [CrossRef]

21. Wu, G. Knowledge collaborative incentive based on inter-organizational cooperative innovation of project-based supply chain. J. Ind. Eng. Manag. 2013, 6, 1065-1081. [CrossRef]

22. Brook, J.W.; Pagnanelli, F. Integrating sustainability into innovation project portfolio management-A strategic perspective. J. Eng. Technol. Manag. 2014, 34, 46-62. [CrossRef] 
23. Reich, B.H.; Gemino, A.; Sauer, C. Knowledge management and project-based knowledge in it projects: A model and preliminary empirical results. Int. J. Proj. Manag. 2012, 30, 663-674. [CrossRef]

24. Javerick-Will, A. Motivating knowledge sharing in engineering and construction organizations: Power of social motiations. J. Manag. Eng. 2011, 28, 193-202. [CrossRef]

25. Benavides-Espinosa, M.D.M.; Ribeiro-Soriano, D. Cooperative learning in creating and managing joint ventures. J. Bus. Res. 2014, 67, 648-655. [CrossRef]

26. Zhang, L.; He, J.; Zhou, S. Sharing tacit knowledge for integrated project team flexibility: Case study of integrated project delivery. J. Constr. Eng. Manag. 2012, 139, 795-804. [CrossRef]

27. Di Vincenzo, F.; Mascia, D. Social capital in project-based organizations: Its role, structure, and impact on project performance. Int. J. Proj. Manag. 2012, 30, 5-14. [CrossRef]

28. Ilies, R.; Judge, T.; Wagner, D. Making sense of motivaitonal leadership: The trail from transformational leaders to motivated followers. J. Leadersh. Organ. Stud. 2006, 13, 1-22. [CrossRef]

29. Avolio, B.J.; Bass, B.M. Multifactor Leadership Questionnaire, Manual and Sampler Set, 3rd ed.; Mind Garden Inc.: Menlo Park, CA, USA, 2004.

30. Bass, B.M. Leadership and Performance beyond Expectations; Free Press: New York, NY, USA, 1985.

31. Bygballe, L.E.; Ingemansson, M. The logic of innovation in construction. Ind. Mark. Manag. 2014, 43, 512-524. [CrossRef]

32. Jiang, W.; Zhao, X.; Ni, J. The impact of transformational leadership on employee sustainable performance: The mediating role of organizational citizenship behavior. Sustainability 2017, 9, 1567. [CrossRef]

33. Bass, B.M.; Riggio, R.E. Transformational Leadership; Lawrence Erlbaum Associates: London, UK, 2006.

34. Uddin, M.A.; Fan, L.; Das, A.K. A study of the impact of transformational leadership, organizational learning, and knowledge management on organizational innovation. Manag. Dyn. 2017, 16, 42-54.

35. Tabassi, A.A.; Roufechasei, K.M.; Ramli, M.; Bakar, A.H.A.; Ismail, R.; Pakir, A.H.K. Leadership competences of sustainable construction project managers. J. Clean. Prod. 2016, 124, 339-349. [CrossRef]

36. Odusami, K.T.; Iyagba, R.R.O.; Omirin, M.M. The relationship between project leadership, team composition and construction project performance in Nigeria. Int. J. Proj. Manag. 2003, 21, 519-527. [CrossRef]

37. Chang, Y.-Y. Multilevel transformational leadership and management innovation: Intermediate linkage evidence. Leadersh. Organ. Dev. J. 2016, 37, 265-288. [CrossRef]

38. Tajasom, A.; Hung, D.K.M.; Nikbin, D.; Hyun, S.S. The role of transformational leadership leadership in innovation performance of Malaysian SMEs. Asian J. Technol. Innov. 2015, 23, 172-188. [CrossRef]

39. Shin, S.J.; Zhou, J. Transformational leadership, conservaiton, and creativity: Evidence from Korea. Acad. Manag. J. 2003, 46, 703-714.

40. Liu, A.M.M.; Chan, I.Y.S. Understanding the interplay of organizational climate and leadership in construction innovation. J. Manag. Eng. 2017, 33, 04017021. [CrossRef]

41. Overall, J. A conceptual framework of innovation and performance: The importance of leadership, relationship quality, and knowledge management. Acad. Entrep. J. 2015, 21, 41-54.

42. Mas-Tur, A.; Ribeiro-Soriano, D. The level of innovation among young innovative companies: The impacts of knowledge-intensive services use, firm characteristics and the entrepreneur attributes. Serv. Bus. 2014, 8 , 51-63. [CrossRef]

43. Mas-Verdu, F.; Ribeiro-Soriano, D.; Roig Dobon, S. Regional development and innovation: The role of services. Serv. Ind. J. 2010, 30, 633-641. [CrossRef]

44. Birasnav, M. Knowledge management and organizational performance in the service industry: The role of transformational leadership beyond the effects of transactional leadership. J. Bus. Res. 2014, 67, 1622-1629. [CrossRef]

45. Singh, S.K. Role of leadership in knowledge management: A study. J. Knowl. Manag. 2008, 12, 3-15. [CrossRef]

46. Han, S.H.; Seo, G.; Yoon, S.W.; Yoon, D.-Y. Transformational leadership and knowledge sharing. J. Work. Learn. 2016, 28, 130-149. [CrossRef]

47. Bryant, S.E. The role of transformational and transactional leadership in creating, sharing and exploiting organizational knowledge. Leadersh. Organ. Stud. 2003, 9, 32-44. [CrossRef]

48. Suparak, S.; Avery, G. Sustainable leadership practices driving financial performance: Empirical evidence from Thai SMEs. Sustainability 2016, 8, 327. 
49. Noruzy, A.; Dalfard, V.M.; Azhdari, B.; Nazari-Shirkouhi, S.; Rezazadeh, A. Relations between transformational leadership, organizational learning, knowledge management, organizational innovaion, and organizational performance: An empirical investigation of manufacturing firms. Int. J. Adv. Manuf. Technol. 2013, 64, 1073-1085. [CrossRef]

50. Wang, Y.; Ho, C. No money? No problem! The value of sustainability: Social capital drives the relationship among customer identification and citizenship behavior in sharing economy. Sustainability 2017, 9, 1400. [CrossRef]

51. Solé Parellada, F.; Ribeiro-Soriano, D.; Huarng, K.-H. An overview of the service industries' future (priorities: Linking past and future). Serv. Ind. J. 2011, 31, 1-6. [CrossRef]

52. Sánchez, A.A.; Marín, G.S.; Morales, A.M. The mediating effect of strategic human resource practices on knowledge management and firm performance. Rev. Eur. Dir. Econ. Empres. 2015, 24, 138-148. [CrossRef]

53. Birasnav, M.; Rangnekar, S.; Dalpati, A. Transformational leadership and human capital benefits: The role of knowledge management. Leadersh. Organ. Dev. J. 2011, 32, 106-126. [CrossRef]

54. Peachey, J.W.; Burton, L.J.; Wells, J.E. Examining the influence of transformational leadership, organizational commitment, job embeddedness, and job search behaviors on turnover intentions in intercollegiate athletics. Leadersh. Organ. Dev. J. 2014, 35, 740-755. [CrossRef]

55. Zhen, Z.; Peterson, S.J. Advice networks in teams: The role of transformational leadership and memebers' core self-evaluations. J. Appl. Psychol. 2011, 96, 1004-1017.

56. Lussier, R. Human Relations in Organizations: Applications and Skill Building, 7th ed.; McGraw-Hill Education: New York, NY, USA, 2006.

57. Chen, L.; Zheng, W.; Yang, B.; Bai, S. Transformational leadership, social capital and organizational innovation. Leadersh. Organ. Dev. J. 2016, 37, 843-859. [CrossRef]

58. Johnson, S.G.; Schnatterly, K.; Hill, A.D. Board composition beyond independence: Social capital, human capital and demographics. J. Manag. 2013, 39, 232-262. [CrossRef]

59. Golmoradi, R.; Ardabili, F.S. The effects of social capital and leadership styles on organizational learning. Procedia-Soc. Behav. Sci. 2016, 230, 372-378. [CrossRef]

60. Turkina, E.; Thai, M.T.T. Social capital, networks, trust and immigrant entrepreneurship: A cross-country analysis. J. Enterp. Communities People Places Glob. Econ. 2013, 7, 108-124. [CrossRef]

61. Tsai, W.; Ghoshal, S. Social capital and value creation: The role of intrafirm networks. Acad. Manag. J. 1998, 41, 464-476. [CrossRef]

62. Alvani, M.; Nategh, T.; Farahi, M. The role of social capital in developing organizaitonal knowledge management. J. Iran's Manag. Sci. 2007, 2, 35-70.

63. Edwards, J.R.; Lambert, L.S. Methods for integrating moderation and mediation: A general analytical framework using moderated path analysis. Psychol. Methods 2007, 12, 1-22. [CrossRef] [PubMed]

64. Brislin, R.W. The wording and translation of research instrument. In Field Methods in Cross-Cultural Research; Lonner, W.J., Berry, J.W., Eds.; Sage: Beverly Hills, CA, USA, 1986; pp. 137-164.

65. Bass, B.M.; Avolio, B.J. Multifactor Leadership Questionnaire; Consulting Psychologists Press: Palo Alto, CA, USA, 1996.

66. McColl-Kennedy, J.R.; Anderson, R.D. Impact of leadership style and emotions on subordiante performance. Leadersh. Q. 2002, 13, 545-559. [CrossRef]

67. Podsakoff, P.M.; MacKenzie, S.B.; Moorman, R.H.; Fetter, R. Transformational leader behaviors and their effects on followers' trust in leader, satisfaction, and organizational citizenship behaviors. Leadersh. Q. 1990, 1, 107-142. [CrossRef]

68. Ming-Huei, C.; Yuan-Chieh, C.; Shih-Chang, H. Social capital and creativity in R\&D project teams. R D Manag. 2007, 38, 21-34.

69. Collins, C.J.; Smith, K.G. Knowledge exchange and combination: The role of human resource practices in the performance high-technology firms. Acad. Manag. J. 2006, 49, 544-560. [CrossRef]

70. Qinxuan, G.; Yishi, F.; Aimin, H. knowledge sharing and organizational performance: The role of knowledge-driven human resource management practice. Nankai Bus. Rev. 2009, 12, 59-66.

71. Brown, T.A. Confirmatory Factor Analysis for Applied Research; Guilford Press: New York, NY, USA, 2006.

72. Bentler, P.M.; Bonett, D.G. Significance tests and goodness of fit in the analysis of covariance structures. Psychol. Bull. 1980, 88, 588-606. [CrossRef] 
73. Hu, L.; Bentler, P.M. Cuttoff criteria for fit indexes in covariance structure analysis: Conventional criteria versus new alternatives. Struct. Equ. Model. A Multidiscip. J. 1999, 6, 1-55. [CrossRef]

74. Browne, M.W.; Cudeck, R. Alternative ways of assessing model fit. Sociol. Methods Res. 1992, 21, $230-258$. [CrossRef]

75. Baron, R.M.; Kenny, D.A. The moderator-mediator variable distinction in social psychological research: Conceptual, strategic, and statistical considerations. J. Pers. Soc. Psychol. 1986, 51, 1173-1182. [CrossRef] [PubMed]

76. Hayes, A.F. An index and test of linear moderated mediation. Multivar. Behav. Res. 2015, 50, 1-22. [CrossRef] [PubMed]

77. Preacher, K.J.; Rucker, D.D.; Hayes, A.F. Addressing moderated mediation hypotheses: Theory, methods, and prescriptions. Multivar. Behav. Res. 2007, 42, 185-227. [CrossRef] [PubMed]

78. Naoum, S. People and Organizational Management in Construction; Thomas Telford: London, UK, 2001.

79. Chan, A.T.S.; Chan, E.H.W. Impact of perceived leadership style on work outcomes: Case of building professionals. J. Constr. Eng. Manag. 2005, 131, 413-422. [CrossRef]

80. Zhu, W.; Chew, I.K.H.; Spangler, W.D. CEO transformational leadership and organizational outcomes: The mediating role of human-capital-enhancing human resource management. Leadersh. Q. 2005, 16, 39-52. [CrossRef]

81. Lin, H.; Hu, T. Knowledge interaction and spatial dynamics in industrial districts. Sustainability 2017, 9, 1421. [CrossRef]

82. Bresnen, M.; Goussevskaia, A.; Swan, J. Embedding new management knowledge in project-based organizations. Organ. Stud. 2004, 25, 1535-1555. [CrossRef]

(C) 2017 by the authors. Licensee MDPI, Basel, Switzerland. This article is an open access article distributed under the terms and conditions of the Creative Commons Attribution (CC BY) license (http:/ / creativecommons.org/licenses/by/4.0/). 